\title{
Effect of vesicular arbuscular mycorrhiza (VAM) on purple blotch and cost economics of onion (Allium cepa) under northern dry zone of Karnataka
}

\author{
D.A. PRAVEENKUMAR* AND N. K. HEGDE
}

University of Horticultural Sciences, BAGALKOT (KARNATAKA) INDIA

\section{ARITCLE INFO}

Received : 25.04 .2017

Revised : 05.08 .2017

Accepted : 19.08.2017

\section{KEY WORDS :}

VAM, Onion, PDI, Purple blotch, Cost of cultivation

*Corresponding author: praveenhrt@gmail.com

\section{ABSTRACT}

An experiment was carried out at Kittur Rani Channamma College of Horticulture, Arabhavi, (UHS, Bagalkot) during Kharif 2012 and Kharif 2013 to find out the effect of vesicular arbuscular mycorrhiza and bio-inoculants on purple blotch disease and cost economics in onion. Per cent disease index for purple blotch differed significantly due to bio-inoculants levels in both the years as well in pooled data. In the pooled data significantly lower per cent disease index at 90 days after transplanting (21.61) was recorded by the treatment $\mathrm{T}_{10}$, followed by the treatment $\mathrm{T}_{11}$ and $\mathrm{T}_{9}$. The treatment $\mathrm{T}_{10}$ resulted significantly higher $\mathrm{B}: \mathrm{C}$ ratio (2.75) in the pooled data.

How to view point the article : Praveenkumar, D.A. and Hegde, N.K. (2017). Effect of vesicular arbuscular mycorrhiza (VAM) on purple blotch and cost economics of onion (Allium cepa) under northern dry zone of Karnataka. Internat. J. Plant Protec., 10(2) : 252-255, DOI : 10.15740/ HAS/IJPP/10.2/252-255. 